\title{
Implementasi Kebijakan dan Proses Pengembangan Koleksi Digital Perpustakaan Perguruan Tinggi Vokasi (Studi Kasus Perpustakaan Politeknik Negeri Malang)
}

\author{
Ach. Nizam Rifqi ${ }^{1}$, Verry Mardiyanto ${ }^{2}$ \\ ${ }^{1}$ Politeknik Negeri Malang, ${ }^{2}$ UIN Sultan Maulana Hasanudin Banten \\ ${ }^{1}$ nizamrifqi@ polinema.ac.id, ${ }^{2}$ verry.mardiyanto@uinbanten.ac.id
}

\begin{abstract}
This paper describes the implementation of policies and the process of developing digital collections with research objects in vocational college libraries with cases in the Malang State Polytechnic library. This paper is based on the implementation of policies and development processes as a whole on a digital library collection with a real qualitative approach to the actions of each activity process. The purpose of this research is to describe the diagram results regarding the processes and results of digital collection policies. The results obtained from this research are, the category of implementation of the digital collection development policy of the State Polytechnic Library of Malang which is divided into 4 policies, namely: the development policy for mapping the sub-discipline of collection science, the policy on the structure of the collection development team, the policy on the implementation time period and the policy on the source of the collection digital. The next results regarding the process of developing a digital collection of the Malang State Polytechnic library are divided into 5 processes, namely: community analysis, selection policies, acquisition, weeding and collection evaluation. From the results of the discussion, the Malang State Polytechnic library has a policy for implementing the digital collection development process so that the results of digital collections can be utilized by students and the academic community as a whole.
\end{abstract}

Keywords: Vocational College Library; Policy Implementation; Digital Collection Development.

\begin{abstract}
Abstrak
Tulisan ini menjelaskan mengenai implementasi kebijakan dan proses pengembangan koleksi digital dengan objek penelitian pada perpustakaan perguruan tinggi vokasi dengan kasus di perpustakaan Politeknik Negeri Malang. Tulisan ini didasarkan pada implementasi kebijakan dan proses pengembangan secara menyeluruh pada koleksi digital perpustakaan dengan
\end{abstract}


pendekatan kualitatif secara nyata pada aksi setiap proses kegiatan. Tujuan dari penelitian ini adalah menggambarkan hasil diagram mengenai proses dan hasil kebijakan koleksi digital. Hasil yang didapatkan dari penelitian ini adalah dari kategori implementasi kebijakan pengembangan koleksi digital upt perpustakaan Politeknik Negeri Malang yang dibagi menjadi 4 kebijakan, yaitu: kebijakan pemetaan subdisiplin ilmu koleksi yang dikembangkan, kebijakan struktur tim pengembangan koleksi, kebijakan periode waktu pelaksanaan dan kebijakan sumber perolehan koleksi digital. Hasil berikutnya mengenai proses pengembangan koleksi digital perpustakaan Politeknik Negeri Malang dibagi menjadi 5 proses, yaitu: analisis kebutuhan pengguna, kebijakan seleksi, akuisisi dan pengadaan, penyiangan dan evaluasi koleksi. Dari hasil pembahasan tersebut perpustakaan Politeknik Negeri Malang sudah memiliki kebijakan untuk pengimplementasian proses pengembangan koleksi digital sehingga hasil koleksi digital dapat dimanfaatkan oleh mahasiswa dan civitas akademika secara menyeluruh.

Kata Kunci: Perpustakaan Perguruan Tinggi Vokasi; Implementasi Kebijakan; Pengembangan Koleksi Digital.

\section{A. PENDAHULUAN}

\section{Latar Belakang}

Adanya perkembangan teknologi informasi dan komunikasi yang telah mendominasi diberbagai sektor diantaranya seperti penggunaan media digital sebagai basis untuk melakukan proses kegiatan yang bermanfaat. Kegiatan tersebut bertujuan untuk mempermudah input, poses dan output pekerjaan. Kegiatan tersebut juga teridentifikasi sebagai hal yang positif dan berguna bagi operator dan pengguna kegiatan. Hasil dari kegiatan tersebut dapat dengan mudah di akses berbagai pihak. Selebihnya juga dapat dijadikan budaya kerja yang berbasiskan digital. Manfaat ini dirasakan sekarang dan untuk masa depan. Manfaat positif dari perkembangan teknologi ini mencakup kemudahan berbagai aspek kehidupan manusia. Teknologi memudahkan, teknologi membuat efisiensi pekerjaan dan waktu dan teknologi mengidentifikasikan entitas kehidupan yang lebih maju. Teknologi juga menjadikan manusia untuk tetap berperilaku kreatif dan inovatif dalam segala hal. Hal tersebut mencirika manusia sebagai makhluk yang terus berkembang, dengan seiringan perkembangan zaman.

Perkembangan-perkembangan teknologi informasi dan komunikasi dalam artian luas mencakup segala hal yang berhubungan dengan kehidupan. Salah satu kehidupan tersebut berada di lingkungan perpustakaan. Jika melihat proses dari kegiatan perpustakaan yang dapat diasumsikan sebagai kegiatan besar dan bermacam-macam maka disimpulkan dalam 3 kegiatan 
besar yaitu input, proses dan output atau dalam bahasa ranah keilmuan perpustakaan adalah pengadaan, pengolahan dan pelayanan serta penyiangan dan pengevaluasian kegiatan perpustakaan dari struktur kegiatan besar tersebut. Kegiatan perpustakaan tersebut di masing-masing subproses kegiatan mempunya aturan-aturan tersendiri. Dalam bahasa hukumnya adalah kebijakan dengan aturan yang berlaku. Aturan tersebut dituliskan dalam selembar kertas dan dibuatkan keputusan yang ditandatangani oleh pimpinan organisasi.

Perkembangan teknologi informasi dan mutu kegiatan atau mutu organisasi adalah salah satu hubungan yang tidak terpisahkan satu dengan yang lainnya. Perkembangan teknologi informasi mendesak berbagai organisasi untuk tetap konsisten dan berinovasi menciptakan pelayanan yang melibatkan teknologi informasi, termasuk perpustakaan. Perpustakaan membutuhkan teknologi informasi untuk menciptakan kegiatan yang memudahkan internal dan pengguna. Perpustakaan membutuhkan kebijakan yang berasal dari hasil implementasi kegiatan yang telah dilaksanakan. Hasil implementasi kegiatan tersebut masih bersifat lisan dan pada norma aturan keseharian sehingga diperlukan kebijakan yang tertuang dalam selembar keputusan. Keputusan tersebut dalam hal ini adalah sebuah kebijakan yang diimplementasikan untuk menuju organisasi yang taat dan sesuai aturan.

Kebijakan diperlukan untuk memulai peningkatan mutu organisasi yang saat ini di setiap organisasi berpedoman untuk meningkatkan kesehatan organisasi dengan kebijakan-kebijakan yang berhubungan dengan perkembangan teknologi informasi. Dalam perpustakaan yang saat ini ditekankan adalah dalam bidang koleksi digital. Apa itu koleksi digital? Koleksi digital dalam koleksi perpustakaan yang sudah digital ini adalah hasil dari digitalisasi koleksi yang tadinya berupa buku-buku atau dalam lembaran kertas. Artinya perpustakaan tersebut dapat dikatakan sudah menjadi perpustakaan digital. Apa itu perpustakaan digital? Menurut (Hartono, 2017) mengemukakan sebuah perpustakaan dengan basis koleksi digital yang dapat diakses melalui jaringan (networks). Artinya perpustakaan saat ini sudah dipastikan merambah masuk ke area perpustakaan digital dengan ditandainya koleksi yang dimiliki dan adanya perkembangan teknologi dan pemanfaatannya di perpustakaan, serta dorongan dari pengguna untuk memberikan kritik dan saran bagi perpustakaan supaya perpustakaan menyediakan koleksi dalam bentuk koleksi digital.

Bagaimana mengenai pengembangan koleksi digital? Perpustakaan sebagai pusat sumber informasi memiliki tuntutan untuk dapat semakin berkembang agar nantinya tidak ditinggalkan oleh para pengguna salah satunya melalui pengembangan koleksi yang tidak hanya terbatas tercetak namun juga berbasiskan digital terlebih juga sumber-sumber internal 
institusi/lembaga agar dapat terkelola dan dimanfaatkan (Rifqi, 2018). Artinya perpustakaan wajib memiliki aturan terkait dengan proses-proses pengembangan koleksi, terlebih lagi dalam hal ini adalah proses pengemabngan koleksi digital. Koleksi yang saat ini menjadi dengan mudah untuk dapat dimiliki, dimanfaatkan dan digunakan kembali sewaktu-waktu untuk kebutuhan informasi pengguna.

Pengembangan koleksi di Indonesia khususnya mempunyai kendalakendala yang berarti. Kendala ini berhubungan dengan internal organisasi. Kendala tersebut seperti masalah dana, anggaran, regulasi, prosedur birokrasi dan belum adanya kebijakan pengembangan koleksi merupakan contoh permasalah yang ada. Strategi perlu dilakukan seperti memperkuat sumber dana, melakukan negoisasi, menginisiasi adanya resource sharing dan sering mengadakan sosialisasi dan survei untuk mendapatkan data mengenai apa saja kebutuhan-kebutuhan informasi terkini yang diinginkan pemustaka (Tyasmara, 2016). Hasilnya dari kendala-kendala tersebut dapat dilakukan pemecahan solusi, yang berguna untuk dikemudian hari dan kesinambungan operasional perpustakaan, khususnya pada pengembangan koleksi.

Suatu pentingnya untuk terus menerus mengembangkan koleksi digital adalah dalam bagian proses-proses yang dilakukan. Sebagaimana hal dalam membuat suatu kebijakan. Implementasi dari kebijakan ini diperlukan untuk membuat proses pengembangan koleksi digital dalam sebuah perpustakaan menjadi lebih nyata. Menurut Merilee S. Grindle, ada dua variable besar yang mempengaruhi keberhasilan implementasi yaitu isi kebijakan (content of policy) dan lingkungan implementasi (context of implementation) (Trisnanti, 2016). Isi kebijakan dan lingkungan tempat implementasi kebijakan sangat dominan dalam menentukan keberhasilan suatu kebijakan. Perpustakaan yang mempunyai khazanah koleksi berupa koleksi yang multidisiplin ilmu dengan fokus utama untuk penyelesaian kebutuhan informasi dari pengguna akankah menjadi tempat yang tepat dalam pengimplementasian kebijakan ini serta dalam kegiatan proses pengembangan koleksi digital perpustakaan?

\section{B. HASIL DAN PEMBAHASAN}

\section{Sumber Daya Informasi Digital}

Pembahasan mengenai pengembangan koleksi tentunya berhubungan dengan konten koleksi yang menjadi sumber informasi. Sama halnya dalam konteks pengembangan koleksi digital, maka konten digital menjadi sumber informasi utama. Berbicara mengenai pengembangan koleksi dalam konteks dunia perpustakaan yang dikembangkan baik pengembangan koleksi tercetak maupun koleksi digital secara konten koleksi keduanya dapat dikatakan sama 
merupakan koleksi sebuah perpustakaan, namun perlu dipahami yang membedakan keduanya disini dari segi wujud satu fisik (cetak) dan yang satu adalah digital serta mekanisme kebijakan dan aturan-aturan dalam proses pengimplementasinya.

Menurut Glossary African Digital Library koleksi digital pada awalnya berisi kumpulan informasi dalam bentuk cetak, namun dilakukan pengkonversian dalam format yang terbacakan oleh computer (Saleh, 2010). Dictionary for Library Information Science (OGLIS) mendefinisikan bahwa koleksi digital adalah suatu koleksi perpustakaan atau arsip yang dikonversikan ke dalam format terbaca oleh mesin (machine-readable format) yang tujuannya adalah untuk pelestarian dan penyediaan akses elektronik (Nurkamilah, 2012). Sedangkan pengertian lainnya mengenai koleksi digital merupakan koleksi yang terdapat di perpustakaan sementara koleksinya mengarah pada e- journal, e-book dan sejenisnya (Agusta, 2019). Merujuk dari ketiga pengertian tersebut bahwa koleksi digital merupakan sumber informasi yang secara wujud berbentuk elektronik dengan akses yang luas melalui perangkat computer dan sejenisnya.

Berbagai koleksi digital tentunya bermacam-macam seperti $e$-book, e-megazine, e-journal, karya referensi yang dipublikasikan secara online, databse online dan lain sebagainya. Dikatakan koleksi digital disini dapat dibaca oleh mesin seperti komputer, walaupun tidak menutup kemungkinan dari beberapa koleksi tersebut juga terdapat versi cetaknya. Format berkas koleksi digital ini dapat terdiri atas berbagai bentuk seperti PDF, JPEG atau TIFF (untuk gambar), MP3 (music) dan MP4 video. Koleksi digital tersebut tentunya bagian dari sebuah perpustakaan dan dapat dilakukan secara luas oleh khayalak pada umumnya.

\section{Kebijakan Pengembangan Koleksi Digital}

Kebijakan pengembangan koleksi digital dibagi menjadi dua pembahasan yaitu konsep dan proses pengembangan koleksi.

\section{Konsep}

Suatu koleksi dalam perpustakaan dapat dipandang sebagai salah satu faktor penunjang eksistensinya perpustakaan. Seiring dengan perkembangan khususnya dalam dunia ilmu pengetahuan dan tuntutan kebutuhan informasi pengguna, koleksi perpustakaan dari waktu ke waktu akan terus mengalami suatu perkembangan. Perkembangan koleksi perpustakaan tersebut dilakukan dengan mengadakan koleksi-koleksi yang mutakhir ke dalam perpustakaan. Implementasinya yaitu ketika melakukan pengadaan koleksi, perpustakaan melakukan pengadaan koleksi yang tidak hanya sebatas menghadirkan koleksi yang mutakhir ke dalam perpustakaan. Akan tetapi dalam 
pengembangan koleksi juga perlu memperhatikan tentang bagaimana sesungguhnya kebutuhan pengguna perpustakaan. Oleh karena itu, pengembangan koleksi perpustakaan perlu dikelola secara profesional agar koleksi perpustakaan berkembang sesuai dengan kebutuhan penggunanya.

Pengembangan koleksi merupakan suatu istilah yang digunakan secara luas di dunia perpustakaan untuk menyatakan bahan pustaka apa saja yang harus diadakan di perpustakaan. Sebelumnya muncul istilah seleksi buku, buku dalam pengertian yang lebih luas yang mencakup monografi, majalah, bahan mikro dan jenis bahan pustaka lainnya. Adapun pengertian pengembangan koleksi (American Library Association, 1983) adalah:

"A term which encompasses a number of activities related to the development of the library collection, including the determination of the library collection, including the determination and coordination of selection policy, assessment of needs of users and potential users, collection evaluation, identification of collection needs, selection of materials, planning for resource sharing, collection maintenance, and weeding".

Jika pengertian Pengembangan Koleksi menurut ALA Glossary of Library and Information Science (1983) di atas diterjemahkan ke dalam bahasa indonesia yaitu; serangkaian kegiatan yang berkaitan dengan penentuan dan koordinasi kebijakan seleksi, menilai kebutuhan pemakai, studi pemakaian koleksi, evaluasi koleksi, identifikasi kebutuhan koleksi, seleksi bahan pustaka, perencanaan kerjasama sumberdaya koleksi, pemeliharaan koleksi dan penyiangan koleksi perpustakaan. Pengertian lain menjelaskan bahwa pengembangan koleksi adalah proses yang sistematis dan esensial untuk membangun koleksi perpustakaan untuk memenuhi kebutuhan pengajaran, pembelajaran, dan penelitian pengguna sasarannya yang didalamnya termasuk akuisisi, seleksi, evaluasi, dan pelestarian sumber daya sesuai dengan kebutuhan pengguna (Kaur \& Rupesh, 2017, p. 108).

Berbicara pengembangan koleksi dalam konteks konten digital atau kita sebut pengembangan koleksi digital dapat dikatakan merupakan serangkaian kegiatan atau proses dalam memperluas koleksi digital untuk ditambahkan dalam konten sebuah perpustakaan digital. Sama halnya dalam konteks perpustakaan konvensional yang koleksinya berupa cetak, pengembangan koleksi perpustakaan digital lebih terfokus pada non cetak. Dengan kata lain perbedaan lebih kepada objek atau bentuk koleksi antara cetak dengan non cetak atau digital. 


\section{Proses Pengembangan Koleksi}

Sebagaimana telah dijelaskan pada pengertian bahwa pengembangan koleksi terdiri dari serangkaian proses kegiatan dalam upaya memperluas koleksi. Evans dalam bukunya "Developing Library and Information Center Collections" menjabarkan model serangkaian proses dalam pengembangan koleksi yang meliputi Community Analysis, Selection Polices, Aquistion sampai pada proses Diselection atau yang kita kenal dengan proses penyiangan weding. (Evans, 1995, p. 18).

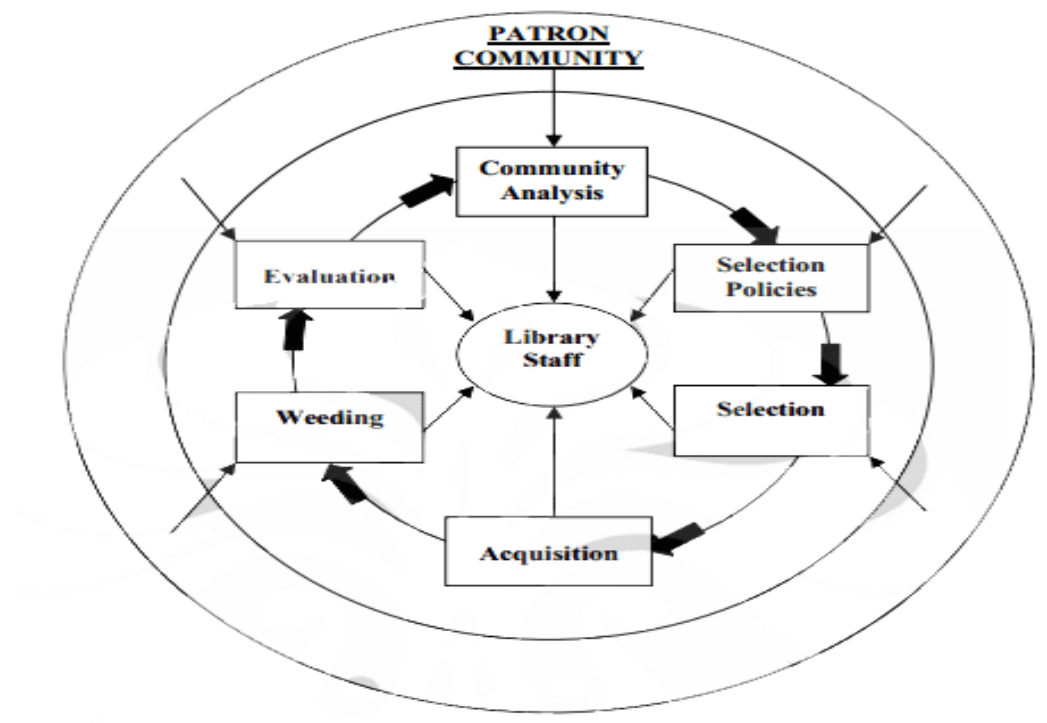

Gambar 1. Collection Development Process

Pada gambar. 1 dijelaskan bahwa lingkaran luar merupakan lingkaran yang mewakili komunitas menjadi pengguna. Lalu adanya tanda panah dari lingkaran luar yang menunjuk pada kontak analisis komunitas, kebijakan seleksi, seleksi, akuisisi, penyiangan dan evaluasi. Dalam proses tersebut juga perlu diperhatikan kebutuhan dan masukan dari pengguna, hal tersebut bertujuan agar nantinya koleksi yang dimiliki oleh perpustakaan benar-benar mencerminkan kebutuhan informasi pengguna.

Community Analysis adalah sebagai bagian dari persiapan untuk kebijakan pengembangan dalam upaya pengumpulan bahan koleksi yang akan dilakukan pengembangan. Tahap ini dilakukan suatu proses analisis pengguna (pemustaka) yang dinaungi terhadap kebutuhan sumber-sumber informasinya. Setelah terindektifikasi dari beberapa kebutuah npengguna tersebut dibuatkan suatu kebijakan dalam seleksi suatu koleksi, dalam konteks ini masuk pada tahapan proses selection policies. Berdasar pada kebijakan yang telah dibuat tersebut baru proses seleksi koleksi barulah 
dapat dilaksanakan. Pada akhirnya, dapat pengguna memanfaatkan informasi berupa koleksi tersebut setelah dilakukannnya tahap accuisition oleh pihak perpustakaan, artinya setelah koleksi setelah melalui proses seleksi dan lanjut dilakukan akuisisi barulah koleksi tersbeut menjadi koleksi milik perpustakaan. Kemudian dalam impelementasinya penggunaan koleksi tersebut dapat pula dilakukan tentunya penyiangan dengan pertimbanganpertimbangan dan kebijakan tertentu, sampai pada tahap akhir dilakukan suatu evaluasi koleksi.

\section{Perpustakaan Perguruan Tinggi Vokasi Politeknik Negeri Malang}

Politeknik Negeri Malang (Polinema) awalnya bernama Politeknik Universitas Brawijaya, berdiri pada tahun 1982 berdasarkan Surat Keputusan Presiden No. 59/Tahun 1982. Politeknik Universitas Brawijaya berkedudukan di Kota Malang, Propinsi Jawa Timur dan merupakan salah satu dari 6 politeknik perintis berdasarkan Surat Keputusan Direktur Jenderal Pendidikan Tinggi No.115/DIKTI/KEP/1984. Sejak tahun 2007 Politeknik Negeri Brawijaya secara resmi berdiri sendiri dan beralih nama menjadi Politeknik Negeri Malang. Secara sistem pengelolaan dan keadministrasianpun dari yang sebelumnya mejadi bagian dari Universitas Brawijaya telah beralih dengan sistem pengelolaan yang menjadi suatu institusi lembaga sendiri.

Berbeda dengan perguruan tinggi seperti universitas pada umumnya, Politeknik Negeri Malang merupakan perguruan tinggi negeri dengan berbasis vokasi. Secara kurikulum sistem pendidikan Polinema menerapkan sistem pendidikan dengan prosentase sistem pembelajaran $70 \%$ praktek dan $30 \%$ teori. Penekanan pembelajaran pada institusi dengan prosentase yang ada lebih menekankan kepada praktek, artinya institusi Politeknik Negeri Malang lebih mempersiapkan kompetensi lulusan yang memiliki skill dan keterampilan dengan harapan mereka ketika lulus dapat langsung terjun kedalam dunia kerja.

Basic keilmuan yang terdapat dalam institusi Polinema terdapat 2 unsur yaitu Rekayasa (Teknik) dan Tata Niaga (Ilmu Sosial) dengan jenjang Diploma 3 (D-3), Sarjana Terapan (D-4), dan Magister Terapan (S-2). Menjadi suatu kewajiban mahasiswa menjelang tingkat akhir melaksanakan program magang diberbagai sektor menyesuaiakan sesuai dengan bidang keilmuan jurusan masing-masing. Berangkat dari dasar kurikulum pendidikan vokasi yang ditempuh oleh Polinema maka hasil akhir mahasiswa dituntut lebih kepada kemampuan untuk membuat suatu produk yang bermanfaat atau produk tepat guna. 


\section{Implementasi Kebijakan dan Proses Pengembangan Koleksi Digital Perpustakaan Politeknik Negeri Malang}

Kebijakan Pengembangan Koleksi Digital UPT Perpustakaan Politeknik Negeri Malang

Hakikat adanya kebijakan pengembangan koleksi adalah dasar acuan pengambilan keputusan yang berkaitan dengan koleksi suatu perpustakaan. Implementasi kebijakan proses pengembangan koleksi digital di UPT Perpustakaan Politeknik Negeri Malang adalah sebagai suatu dasar acuan yang digunakan sebagai pijakan dalam pengambilan keputusan mengenai ketentuan prosedural secara teknis yang telah ditetapkan oleh pihak UPT Perpustakaan Politeknik Negeri Malang dalam kegiatan pengembangan koleksi perpustakaan. Adanya suatu kebijakan pengembangan koleksi digital ini oleh UPT Perpustakaan Politeknik Negeri Malang agar perpustakaan dapat menyediakan digital content yang dibutuhkan oleh para pengguna khususnya sivitas akademika Politeknik Negeri Malang secara tepat sasaran dan terarah.

Kebijakan Pemetaan Subdisiplin Ilmu Koleksi yang dikembangkan

Berdasarkan pada background keilmuan institusi Polteknik Negeri Malang di mana merupakan suatu institusi perguruan tinggi dengan basis keilmuan terapan, maka tentunya arah pengembangan koleksi khususnya digital sejalan dengan keilmuan institusi yaitu dipriritaskan pada basis subyek keilmuan terapan. Fokus pengembangan koleksi dengan berdasar pada jurusan dan prosi yang terdapat pada Politeknik Negeri Malang, di mana masing-masing jurusan dan prodi tersebut memiliki bidang kajian subyek keilmuan dan konsentrasi yang berbeda.

Subyek keilmuan terapan yang ada di institusi Politeknik Negeri Malang dengan merujuk pada jurusan dan prodi yang ada secara garis besar terdiri dari 2 subyek yaitu tata niaga dan rekayasa. Istilah tataniaga sendiri merujuk pada bidang yang berkaitan dengan masalah ekonomi dan bisnis yang berkaitan dengan barang/jasa, maupun kegiatan administrasi perkantoran. Sedangkan untuk rekayasa yaitu berkaitan dengan bidang teknologi untuk menyelesaiakan suatu permasalahan, disini dapat dikatakan berhubungan dengan bidang teknik dan teknologi informasi. Berikut merupakan tingkat prosentase pengembangan koleksi UPT Perpustakaan Politeknik Negeri Malang berdasarkan subdisiplin keilmuan yang dikaji pada Politeknik Negeri Malang: 
Tabel 1. Prosentase pengembangan koleksi digital UPT Perpustakaan Politeknik Negeri Malang berdasarkan sistem DDC (Dewey Decimal Classification)

\begin{tabular}{llc} 
No. & Subdisiplin & $\begin{array}{c}\text { Prosentas } \\
\text { e }\end{array}$ \\
\hline 1. & Kaya umum (Penelitian, Ilmu Komputer) & $10 \%$ \\
\hline & Filsafat \& Psikologi & - \\
\hline $\begin{array}{l}\text { Agama (Ilmu Al-Qur'an dan Hadis, Fikih, } \\
\text { Akhlak dan Tasawuf) }\end{array}$ & - \\
\hline $\begin{array}{l}\text { Ilmu Sosial (Pengantar Sosial, Ekonomi, } \\
\text { Sosiologi, kewarganegaraan) }\end{array}$ & $30 \%$ \\
\hline Bahasa (Indonesia, Inggris, Mandarin) & - \\
\hline Ilmu Murni (Matematika, Fisika, Kimia) & $15 \%$ \\
\hline $\begin{array}{l}\text { Ilmu Terapan (Manajemen, Teknik Mesin, } \\
\text { Sipil, Kimia Terapan, Bangunan) }\end{array}$ & $30 \%$ \\
\hline Kesenian (Tata Kota, Arsitektur Bangunan) & $15 \%$ \\
\hline Kesusatraan (Novel fiksi dan non fiksi) & - \\
\hline $\begin{array}{l}\text { Geografi \& Sejarah (Biografi Tokoh, Ilmu } \\
\text { Sejarah) }\end{array}$ & - \\
\hline Jumlah & $\mathbf{1 0 0 \%}$
\end{tabular}

Jumlah prosentase secara teknis dilakukan dengan menyesuaikan jurusan serta prodi kajian yang terdapat di Politeknik Negeri Malang. Prosentase bersifat fleksibel sewaktu-waktu dapat mengalami perubahan sesuuai dengan perkembangan di Politeknik Negeri Malang.

Kebijakan Struktur TIM Pengembangan Koleksi

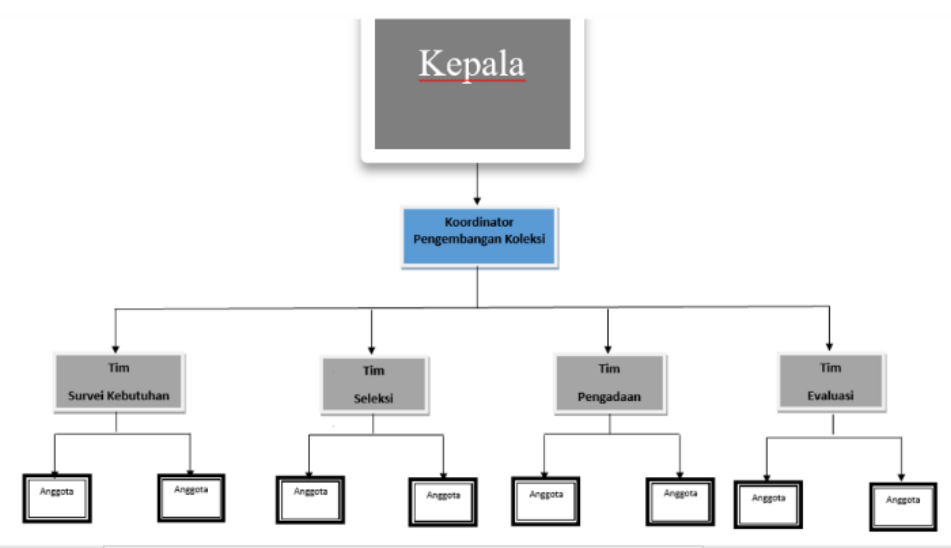

Gambar 2. Struktur keanggotaan kegiatan pengembangan koleksi perpustakaan 
Proses pelaksanaan pengembangan koleksi di bentuk suatu struktur sebagai garis koordinasi dalam proses pelaksanaan pengembangan koleksi. Perlu dipahami struktur TIM disini dibentuk tidak secara khusus pada konten digital saja, namun mencakup seluruh kegiatan pengembangan koleksi di UPT Perpustakaan Politeknik Negeri Malang, baik itu tercetak ataupun non cetak. Untuk pemangku kebijakan tertinggi berada pada level kepala dan koordinator dibawah kepala sebagai ketua teknis kegiatan. Pada proses pelaksanaan koordinator ditunjuk sebagai ujung tombak yang bertanggung jawab dalam proses kegiatan yang meliputi: survei kebutuhan, proses seleksi, pengadaan dan evaluasi. Pada kegiatan dilakukan dengan membentuk suatu tim per jenis kegiatan dengan terdapat masing-masing anggota di dalamnya. Berkaitan dengan pengembangan koleksi digital maka kegiatan tentunya yang berkaitan dengan proses: survei kebutuhan, proses seleksi, pengadaan sampai evaluasi dalam konteks pengembangan koleksi digital.

\section{Kebijakan Periode Waktu Pelaksanaan}

Pelaksanaan proses pelaksanaan kegiatan pengembangan koleksi digital secara umum dilakukan sepanjang tahun, di mana proses kegiatan berlangsung sebagai suatu rutinitas keseharian sebagai salah satu pekerjaan rutin pustakawan. Namun secara formal proses pengajuan yang berhubungan dengan anggaran dan pelaksanaan pengadaan barang dilakukan setiap periode antara bulan september-oktober per tahun. Periode waktu pelaksanaan kegiatan ini mencakup beberapa kegiatan yang tersusun dan telah direncanakan pada tahun sebelumnya. Kebijakan saat ini tergantung dari prosedur yang sudah dilakukan pada periode sebelumnya. Artinya kebijakan ini mengarah pada tradisi pola pengembangan pengmbangan koleksi digital. Secara umum kebijakan pengembangan koleksi digital UPT perpustakaan Polinema berhubungan dengan bagian pengadaan pusat dan erat kaitannya dengan anggaran yang tentunya langsung berhubungan dengan anggaran yang disediakan pihak Politeknik Negeri Malang sendiri untuk perpustakaan.

\section{Kebijakan Sumber Perolehan Koleksi Digital}

Secara umum baik itu koleksi cetak dan non cetak pengkategorian sumber perolehan koleksi UPT Perpustakaan Politeknik Negeri Malang dikategorikan berdasarkan 3 jalur yang meliputi: Hadiah, Hibah dan Pembelian. Khusus untuk koleksi digital pihak perpustakaan memperolehnya sebagian besar melalui pembelian dan hibah. Pembelian dalam beberapa tahun terakhir lebih kepada e-book dan berlangganan portal e-journal. Sedangkan untuk hibah sebagian besar yang tergolong dalam konten 
repository institusi yaitu berupa hasil Tugas Akhir mahasiswa yang diserahkan ke pihak perpustakaan, serta beberapa hasil laporan penelitian dan pengabdian Dosen dan karyawan fungsional tertentu. Adapun sebagian kecil perpustakaan memperoleh dari sumber-sumber akses free e-resources seperti dari Perpustakaan Nasional Republik Indonesia dan beberapa link akses lainnya serta 2 tahun terakhir pihak perpustakaan mendapatkan fasilitas akses beberapa portal jurnal dari kemenristek dikti yang sekarang sudah beralih menjadi kemendikbud.

\section{Proses Pengembangan Koleksi Digital UPT Perpustakaan Politeknik Negeri Malang}

Analisis mengenai bagaimana proses pengembangan koleksi digital di UPT Perpustakaan Politeknik Negeri Malang, dilakukan dengan merujuk pada konsep Collection Development Process yang dikemukakan oleh Evans 1955. Secara rinci proses pengembangan koleksi digital yang ada di UPT Perpustakaan Politeknik Negeri Malang dijabarkan sebagai berikut:

\section{Analisis Kebutuhan Pengguna (Community Analysis)}

Tahap analisis kebutuhan pengguna merupakan salah satu tahap awal dalam proses pengembangan koleksi. Tahap ini dilakukan untuk mengetahui bagaimana dan apa saja yang menjadi kebutuhan pengguna UPT Perpustakaan Politeknik Negeri Malang, serta perpustakaan dapat melakukan suatu pemetaan mengenai koleksi apa sajakah yang menjadi perlu dan penting untuk di adakan dengan menerapkna suatu skala prioritas dalam pengadaan. Kegiatan analisis kebutuhan pengguna perpustakaan bekerja sama dengan pihak jurusan untuk mengumpulkan informasi-informasi terkait baik berupa dokumen dan sarana penunjang lainnya. Dalam hal ini perpustakaan membentuk suatu tim survei yang dikomandoi oleh pustakawan bagian koordinator pengembangan koleksi. Selanjutnya tim yang telah terbentuk disebar pada tiap-tiap jurusan untuk mengumpulkan informasi dan data-data yang dibutuhkan.

Implementasi dari analisis kebutuhan pengguna yang dilakukan oleh UPT Perpustakaan Politeknik Negeri Malang adalah dengan melakukan suatu survei kepada para pengguna perpustakaan, khususnya dalam ruang lingkup civitas akademika Politeknik Negeri Malang. Proses survei dilakukan dengan menentukan apa yang menjadi bauran pemasaran (konsumen) perpustakaan yang meliputi: Dosen, Karyawan dan Mahasiswa. Data hasil survey khususnya yang sering diperoleh dari dosen berupa rekomendasi e-book, subyek e-journal yang mereka butuhkan dalam pembelajaran dikumpulkan oleh pihak perpustakaan untuk segera ditindak lanjuti. 
Gambar berikut ini adalah mengenai prosedur survei kebutuhan mahasiswa. Prosedur kebutuhan mahasiswa tersebut ditekankan pada koleksi-koleksi yang dibutuhkan dengan dihubungkan terhadap mata kuliah yang sedang ditempuh. Misalkan dalam satu semester, baik ganjil atau genap. Mahasiswa menempuh mata kuliah yang berhubungan dengan teknologi informasi maka kebutuhan mahasiswa di semester selanjutnya sudah terpenuhi namun disesuaikan dengan perkembangan teknologi informasi. Cara ini juga dilakukan dengan turun langsung ke lapangan dengan mensurvei dan memberikan semacam angket untuk diisi, kemudian dilakukan Analisa data yang hasil simpulan data tersebut digunakan untuk kebijakan selanjutnya.

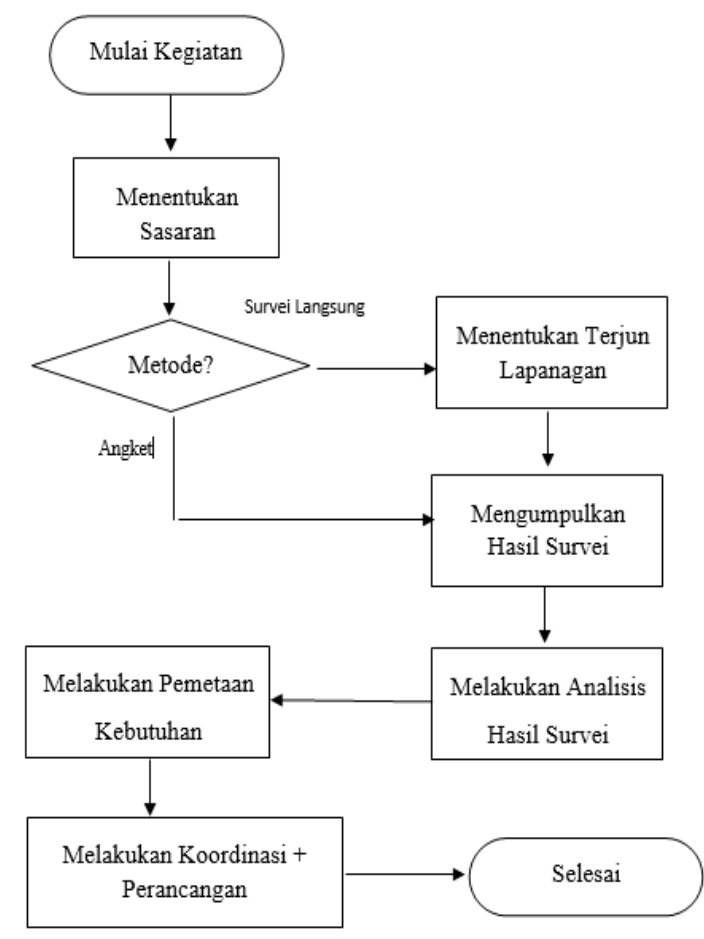

Gambar 3.Prosedur survei kebutuhan pengguna

\section{Kebijakan Seleksi (Selection Policies)}

Seleksi bahan koleksi digital perpustakaan pada prinsipnya disini lebih diprioritaskan untuk koleksi yang diadakan secara pembelian khususnya ketika pihak perpustakaan akan berlangganan portal e-journal tertentu. Proses seleksi dilakukan setelah data dari tahap analisis kebutuhan pengguna telah dikumpulkan dengan membentuk tim seleksi yang terdiri dari 
pustakawan dengan spesialis subyek terkait, koordinator dan tim pengadaan serta perwakilan dosen ataupun orang yang berkompeten. Berikut ini merupakan prosedur alur proses seleksi:

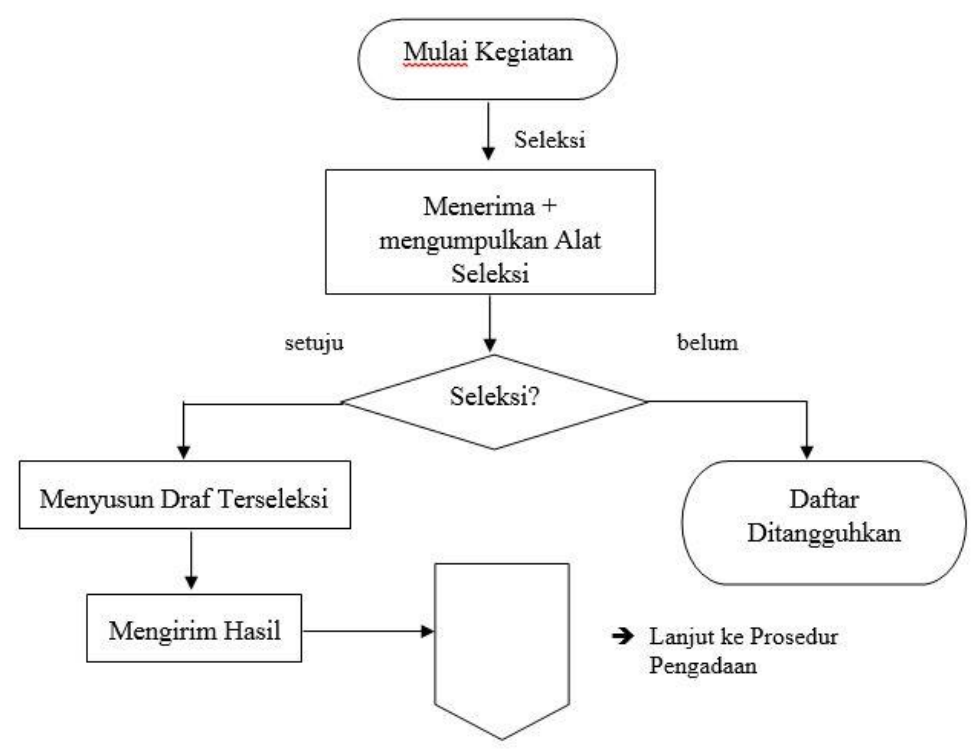

Gambar 4.Prosedur Seleksi

UPT Perpustakaan Politeknik Negeri Malang memiliki kriteria dalam melakukan seleksi bahan koleksi digital yaitu dengan menitik beratkan pada aspek-aspek tertentu dengan penjabaran sebagai berikut:

a) Aspek Tujuan: Tujuan dilakukan agar kegunaan koleksi digital tersebut dapat terlihat kebermanfaatannya secara langsung, dengan kriteria:

- Menjadi pedoman dalam kegiatan belajar mengajar sivitas akademika,

- Memberikan informasi tentang perkembangan ilmu pengetahuan,

- Menciptakan kreativitas, inspirasi, dan inovasi baru,

- Dipakai sebagai hiburan (rekreasi intelektual).

b) Aspek Mutu: Mutu erat kaitannya dengan kualitas adapun yang harus diperhatikan adalah:

- Pengarang dan penerbit memiliki kecakapan autoritas, kejujuran, dan kredibilitas, 
- Bahan perpustakaan termasuk dalam buku-buku terpilih dan terlaris,

- Tinjauan/ resensi buku yang dimuat dalam surat kabar atau majalah.

c) Aspek Isi:

- Topik bahasan yang terdapat dalam konten berisi informasi yang jelas dan mendalam,

- Ilmu untuk bidang kajian pokok yang sesuai dengan kajian Politeknik di prioritaskan pada yang lebih bersifat terapan,

- Mengandung gagasan baru yang bersifat informatif,

- Mengilhami ide-ide atau kreasi baru,

- Mutakhir,

- Konten diperuntukkan sesuai kebutuhan sivitas akademika.

d) Aspek Bahasa: Konten lebih diprioritaskan yang berbahasa inggris. Hal tersebut juga sejalan sebagian besar konten digital seperti e-book, e-journal sebagian besar berbahasa inggris. Adapaun sebagaian kecil yang berbahasa Indonesia adalah hasil Tugas Akhir mahasiswa dan laporan penelitian pengabdian Dosen karyawan fungsional tertentu.

e) Aspek Harga: Harga sebagai sebuah acuan kekuatan dalam penentuan berapa jumlah konten yang akan diadakan. Hal tersebut karena sangat berkaitan dengan masalah dana/anggaran yang dimiliki.

f) Aspek Waktu: Bahan perpustakaan yang dipilih haruslah bahan perpustakaan yang terbaru, tidak ketinggalan zaman (up to date), edisi terbaru, dan belum dimiliki oleh UPT Perpustakaan Politeknik Negeri Malang.

\section{Akuisisi dan Pengadaan (Acquisition)}

Hasil seleksi selanjutnya ditindak lanjuti dengan melakukan pengadaan koleksi. Ketika berbicara masalah implementasi dari pengadaan koleksi tentunya masing-masing tempat, instutisi memiiki teknis pelaksanaan yang berbeda - beda. Implementasi pengadaan UPT Perpustakaan Politeknik Negeri Malang langsung dibawah arahan koordinator pengembangan koleksi sebagai penanggung jawab.

Proses pengadaan koleksi sebagaimana diketahui terdiri dari 2 sumber yaitu melalui pembelian dan hibah. Sejauh ini koleksi digital yang melalui pembelian adalah berupa e-book, e-journal yang berupa pihak perpustakaan berlangganan melalui portal-portal e-journal. Sedangkan untuk 
koleksi digital yang berasal dari hibah sebagian besar berupa hasil karya ilmiah seluruh sivitas akademika Politeknik Negeri Malang. Bagi kalangan mahasiswa mereka wajib menyerahkan konten hasil Tugas Akhir Laporan akhir (D3), Skripsi (D4) dan Tesis (S2 Terapan). Kalangan dosen dan karyawan fungsional tertentu menyerahkan hasil alporan penelitian dan pengabdian.

Terhitung sejak tahun 2016 pihak perpustakaan mulai melanggan beberapa portal e-journal dengan spesifikasi subyek yang berbeda-beda yang anatar lain sebagai berikut:

Tabel 2 Portal e-journal berlangganan

UPT Perpustakaan Politeknik Negeri Malang

\begin{tabular}{ccc}
\hline No. & Portal e-journal & Subyek \\
\hline 1. & Emerald Insight & Ilmu Ekonomi \\
\hline 2. & ProQuest & $\begin{array}{c}\text { Ilmu Ekonomi \& Ilmu } \\
\text { Teknik }\end{array}$ \\
\hline 3. & Gale & Ilmu Teknik \\
\hline
\end{tabular}

Adapun secara prosedur alur proses pengadaan adalah sebagai berikut ini:

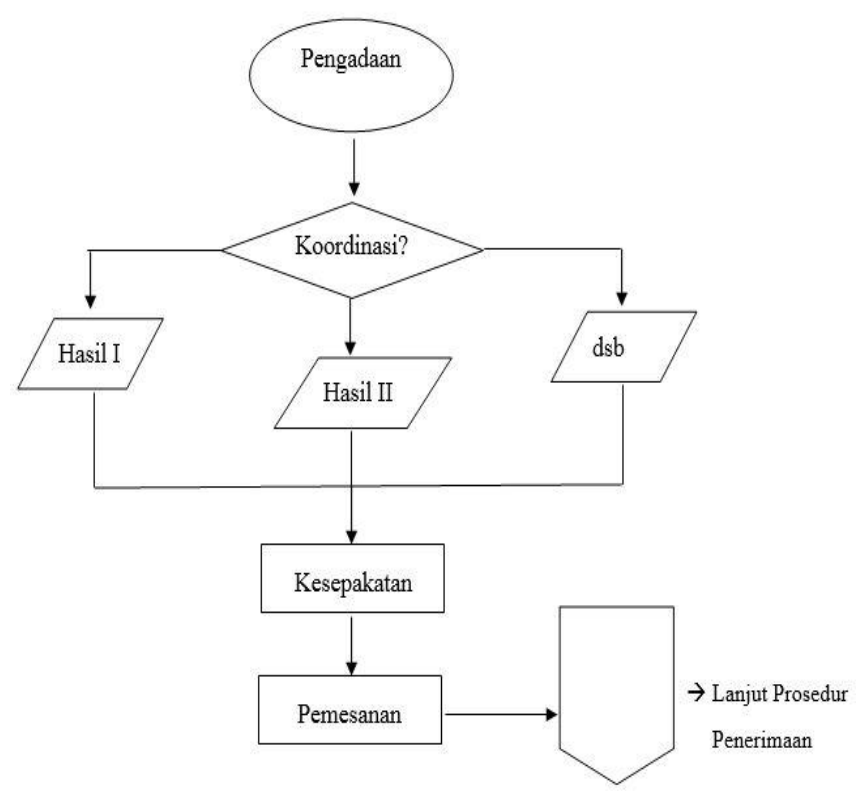

Gambar 5.Prosedur Pengadaan 


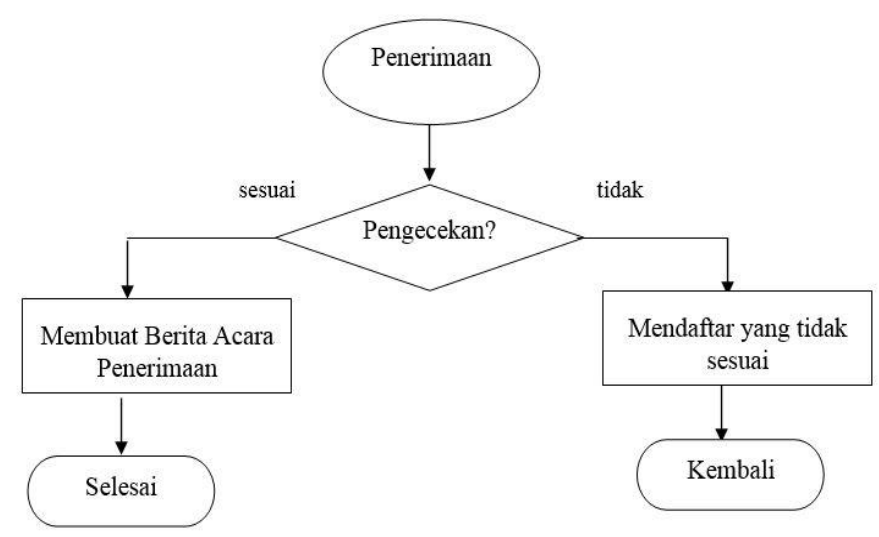

Gambar 6. Prosedur Penerimaan

\section{Penyiangan (Weeding)}

Kegiatan perbaikan dan penyiangan koleksi lebih terfokus pada koleksi tercetak untuk koleksi digital pihak perpustakaan hanya menerapkan pada konten repository seperti Tugas Akhir mahasiswa yang 5 tahun ke bawah sudah tidak dilakukan publish. Selebihnya untuk portal jurnal berlangganan jika sudah tidak berlangganan sudah secara otomatis portal tersebut tidak dapat dilakukan akses samapi ada proses perpanjangan dan langganan baru kembali.

\section{Evaluasi Koleksi (Evaluation)}

Evaluasi bahan koleksi digital UPT Perpustakaan Politeknik Negeri Malang dilakukan sebagai upaya untuk mengkondisikan konten koleksi yang dilayankan kepada pengguna dengan sebaik mungkin dan selayak mungkin agar koleksi yang dilakukan pengembangan dapat tepat sasaran. Sejauh ini yang telah perpustakaan lakukan untuk evaluasi konten digital lebih terfokus kepada tingkat pemakainnya diantaranya seperti melihat statistik penggunaan baik untuk beberapa portal e-journal dan portal repository hasil karya internal sivitas akademika Politeknik Negeri Malang. Berangkat dari hal tersebut, khususnya terkait portal berlangganan sebagai bahan pertimbangan apakah ditahun - tahun berikutnya tetap berlangganan, menambah konten untuk berlangganan ataukah mengurangi dan bahkan berhenti karena tingkat pemakaiannya yang sangat rendah. 


\section{KESIMPULAN}

Implementasi kebijakan dan proses pengembangan koleksi digital merupakan kegiatan yang penting dan wajib dilakukan oleh perpustakaan. Kegiatan ini menggambarkan berbagai hal mengenai kebijakan internal perpustakaan yang dituangkan dalam aturan hukum yang berlaku di perguruan tinggi, dalam hal ini adalah surat keputusan tertandatangan ketua atau rector atau pembantu ketua. Implementasi kebijakan ini menjadikan tingkat mutu perpustakaan meningkat, sehingga perpustakaan dapat menyempurnakan layanannya dan akhirnya dapat dimanfaatkan oleh pengguna secara baik dan sesuai aturan. Perpustakaan juga dapat meningkatkan mutunya terkait dengan akredetasi perpustakaan. Kebijakan ini didorong untuk menyelaraskan perpustakaan perguruan tinggi vokasi dengan subdisplin ilmu yang sudah ditetapkan perguruan tinggi. Kebijakan lainnya mengatur dengan tim internal perpustakaan untuk dapat mengembangkan koleksi digital. Selain itu juga perpustakaan Politeknik Negeri Malang mengatur kebijakan waktu atau periode dan kebijakan perolehan sumber digital. Simpulan kebijakan ini membuat perpustakaan secara jelas dan detail yang akhirnya perpustakaan Politeknik Negeri Malang dapat meningkatkan mutu organisasi perpustakaan.

Selanjutnya mengenai proses pengembangan koleksi digital. Simpulan tulisan ini dijabarkan dalam kelima proses pengembangan koleksi digital. Pengembangan koleksi digital ini memahami dari konsep Evans yang disesuaikan dengan keadaan nyata dalam proses pengembangan koleksi digital. Proses ini dilakukan yang hasilnya dapat dicapai secara signifikan dengan asumsi bahwa kelima proses tersebut harus dilakukan dan dijadikan pedoman. Selain itu juga, proses-proses tersebut wajib ditaati oleh tim perpustakaan. Hasil yang dicapai jika konsisten diterapkan dan terus diimplementasikan baik itu kebijakan dan proses pengembangan koleksi digital adalah tercapainya mutu organisasi perpustakaan Politeknik Negeri Malang yang dapat bersaing di era teknologi informasi. Terlebih lagi kebutuhan koleksi digital yang saat ini semakin tinggi dan semakin dibutuhkan di era informasi ini. Maka dengan satu sentuhan koleksi digital yang mana pengguna dapat langsung membuka koleksi tersebut serta dapat memenuhi kebutuhan informasinya. maka perlu dikembangkan lebih lanjut mengenai proses-proses pengembangan koleksi digital yang sesuai dengan perkembangan zaman. Oleh karena itu, perpustakaan Politeknik Negeri 
Malang memerlukan konsistensi implementasi kebijakan dan proses pengembangan koleksi digital secara baik dan menyeluruh serta menyesuaikan keadaan terkini.

\section{DAFTAR RUJUKAN}

Agusta, A. S. (2019). Proses Pengembangan Koleksi Serial Elektronik: Pengembangan Koleksi Digital Layanan Serial Elektronik Perpustakaan UIN Sunan Kalijaga Yogyakarta. Jurnal Iqra', 13(2), 178-206.

American Library Association. (1983). ALA Glossary of Library and Information Science.

Evans, G. E. (1995). Developing Library and Information Center Collection (3rd ed.). Libraries Unlimited.

Hartono, H. (2017). Strategi Pengembangan Perpustakaan Digital Dalam Membangun Aksesibilitas Informasi: Sebuah Kajian Teoritis pada Perpustakaan Perguruan Tinggi Islam di Indonesia. UNILIB : Jurnal Perpustakaan, 8(1), 75-91.

Kaur, R., \& Rupesh, G. (2017). Collection development in academic libraries with special reference to digital era. International Journal of Digital Library Services.

Nurkamilah, S. (2012). Implementasi Perpustakaan Digital: Studi Komparasi antar Perpustakaan Universitas di Yogyakarta. Universitas Islam Negeri Sunan Kalijaga.

Rifqi, A. N. (2018). Implementasi Sistem Institutional Repository Hasil Karya Ilmiah Sivitas Akademika Politeknik Negeri Malang (Studi Pengembangan Sistem Menggunakan System Development Life Cyle: SDLC). Publication Library and Information Science, 2(1), 1.

Saleh, A. R. (2010). Manajemen Perpustakaan. Universitas Terbuka.

Silvia, \& Rahmah, E. (2014). Pengembangan Koleksi Perpustakaan di Kantor Arsip Perpustakaan dan Dokumentasi Kota Padang. Jurnal Ilmu Informasi Perpustakaan Dan Kearsipan, 3(1), 95-103.

Trisnanti, M. (2016). Studi Mengenai Implementasi Kebijakan Program Layanan Referensi di Perpustakaan Universitas Surabaya. Trabajo 
178 | TIK ILMEU: Jurnal IImu Perpustakaan dan Informasi, vol. 4, no. 2, 2020

Infantil, 1689-1699.

Tyasmara, N. C. (2016). Pengembangan Koleksi Perpustakaan: Tantangan Dan Pembelajaran Sepanjang Hayat. 1-8. 